\title{
Democratic Changes and Economic Growth
}

\author{
Gennady Bilych \\ Dept. of Management, UPEC Corporation, Belgorod \\ 20 Popova str., 308000, Belgorod, Russia
}

Tel: 7-472-220-2033Ｅ-mail: genatdht@yandex.ru

Received: May 2, 2013 Accepted: May 20, 2013

doi:10.5296/ber.v3i1.3608 URL: http://dx.doi.org/10.5296/ber.v3i1.3608

\begin{abstract}
Today it must be admitted that there is no significant connection between the level of development of democratic institutes and the value of economic growth. This conclusion invariably stems from the vast amount of theoretical and empirical studies that have been conducted over the last 50 years. Why have developed democracies become economic leaders? Why is the US economy growing faster than the economy in Angola, but slower than the economy in Botswana? There are still no answers to these seemingly simple questions. In this paper the author attempts to theoretically justify and empirically confirm the link between the democratic changes in countries and their economic growth. This link becomes apparent if we assume that the amount of transaction costs of exchange depends on the level of political and economic freedom. In turn, transaction costs have a significant influence on the effective functioning of the economy. A decrease in costs of exchange speeds up economic growth and an increase in costs slows down growth. This kind of approach enables us to explain the economic successes of democracies, the lagging behind of many countries in Asia and Africa, the historical reasons for the beginning of the industrial revolution in Europe, the speeding up of economic growth in the $18^{\text {th }}-19^{\text {th }}$ centuries, the rapid development of production in China and many other occurrences.
\end{abstract}

Keywords: Economic growth, Democratic changes, Transaction costs, Industrial revolution

\section{Introduction}

The work of Lipset (1959) sparked an entire wave of studies into the link between the level of development of democratic institutes and economic growth. Lipset highlighted the fact that all democratic countries had achieved high income per capita figures. The gap between democracies and autocracies in this respect is not only failing to decrease with time, but is continuing to increase. This, of course, requires an explanation. The science of the wealth of 
nations and peoples cannot leave such questions unanswered for long. For economists, many of whom are advisors to political leaders and parties, the explanation of the link between a democracy and economic development is a matter of honour, a test of professional competence. Economists have, of course, legitimately argued that there is a positive link between the level of freedom in a country and economic growth. However, bitter disappointment lay in wait for them on this path. It has not been possible to find a definite relationship between these indicators.

Lipset's observation that the wealthier a nation is the more likely it is that it will approve a democracy is encouraging, but it does not explain anything. Countries in Europe and North America chose the democratic path of development a relatively long time ago; therefore the average resident in almost all countries with dictator regimes long since became wealthier than the average European 200 years ago. However, dictatorships stubbornly continue to exist, although it must be said that they are becoming fewer in number. Every historical era and every country does have its own story, of course. Countries differ from each other in terms of cultural traditions, religions, historic past, geographical location, the natural resources present and many other features. If we assume that the development of institutes is determined by similar features, then economists should look at other problems and leave the discussion of democracies and dictatorships to specialists of other disciplines. I ought to point out the words of Rawls (1971) that human rights, including political rights, are valuable in their own right. They cannot be the object of political bargaining, or used as a bargaining chip when calculating public interests. Furthermore, one question remains unanswered: why is it that certain countries, which are far from democracy, demonstrate impressive growth rates, much higher than in mature democracies? One cannot help but agree with North's (2005) view that dictators can create efficient institutes that promote the growth of welfare. These words turn economics into a dismal science and there is nothing left for optimists to do. Better to pollinate flowers or search for extra-terrestrial intelligence.

However, things are not as bad as they seem at first glance. Institutes undoubtedly have an influence on economic development (North, 2005; Greif, 2006; Johnson, 2000) and consequently they determine the level of economic growth. There is indeed a link between democracy and growth, but it is not direct; it is rather complex. I am certain that economic growth in any country which takes place over a certain period of time depends on the change in the level of democracy over that period of time. The greater the change, the more growth there is. If democratic rights become weaker and the changes are negative, there will be a significant reduction in economic growth. In this case negative growth may even be observed, i.e. a decrease in the production of goods and services. This approach explains many events that are taking place today or have happened in the past. Some dictatorships may demonstrate high growth rates if, at a certain moment in time, the country experiences an improvement in the situation with political and economic freedoms. Established democracies have average growth rates because it is not at all easy to improve democratic institutes that are sufficiently developed. Improvements such as these cannot happen quickly; it is a lengthy evolutionary process. Therefore the trajectories of development of countries may converge and they may also diverge. It becomes clear why Europe and North America are today's economic leaders. The 
democratic changes of the last 500 years in these areas of the world were the most significant and therefore they have the highest level of economic growth over that period. Why is growth dependent upon these changes? We will answer this question later, but now we need to discuss the work of economists that appeared after the famous Lipset article.

\section{Literature Survey}

\subsection{Democracy. Economic and Political Rights}

People studying the relationship between democracy and growth inevitably come up against the problem of determining the complex and ambiguous term of "democracy". Welzel and Inglehart (2008) rightly observed that universal suffrage is not in fact democracy. There is nothing preventing the population of a country from electing a dictator and there are well-known examples of this. Naturally, this is not possible in established and developed democracies, but in younger democracies it is entirely likely. Not too long ago there was a mass phenomenon called "illiberal democracies" (Zakaria, 2003). There are a fair number of countries where fully competitive elections are held, but there are no freedoms. It would, of course, be an exaggeration to include these countries among developed democracies. Freedoms are an end goal and also a necessary condition for a democracy to exist. However, the question that invariably arises is which freedoms are more important? Which should be taken into consideration first, political freedoms, or economic freedoms? Which freedoms have a greater effect on growth? Let us try and find this out. Many people believe Singapore to be a strange and surprising exception to the rule; it combines an authoritarian model of government with a high level of income of residents (Sen, 1997). However, nobody takes into consideration the very high level of economic freedom of citizens. Singapore is second in the world in terms of this indicator, behind Hong Kong (Index of Economic Freedom. The Heritage Foundation and The Wall Street Journal). The US is in $10^{\text {th }}$ place, Germany $19^{\text {th }}$ and Japan $24^{\text {th }}$. Evidently the low level of political freedom in Singapore is compensated by a high level of economic freedom and therefore it is no surprise that this country is one of the world's economic leaders. Some authors (Okui, 2005; Wo, 2005) believe that political and economic freedom are in no way linked to one another. They exist completely independently of each other; they do not interact at all and have no effect on the other. Few people agree with this, the majority have another point of view. As pointed out by McGuire and Olson (1996), a dictator seeks to increase their financial returns or the difference between tax revenues and expenses connected with public benefit, whilst democratic governments are interested in maximizing public benefit. This is confirmed by Lake and Baum (2001); democracies provide a greater amount of public benefits such as healthcare and education. Wilke (2002) notes the high level of taxation and various hidden payments under dictatorships. High taxes do seriously infringe upon economic freedoms and therefore one should not hasten to argue that political freedoms are in no way linked to economic freedom. And if we also consider the constant and inevitable threat to rights of ownership in non-democratic countries, then we have to recognize the close link between political and economic freedom. Therefore the level of democracy is directly linked to the levels of political and economic freedom. A democracy is a sum of political and economic rights. Of course, a dictator may conduct a liberal policy, provide citizens a relatively wide range of rights, perform limited functions and not interfere in political processes. But a regime 
such as this could not be called a dictatorship; it is more a transition from a dictatorship to a democracy. Any increase in economic rights leads to an increase in political rights and vice versa.

\subsection{Democracy and Growth}

Another problem arises when studying the link between democracy and growth. Today there is no consensus as to which of these values is dependent. Some researchers believe that the level of democracy determines the value of economic growth (Feng, 2003; Papaioannou and Siourounis, 2008; Gerring et al., 2005; Persson and Tabellini, 2006). Others believe that growth causes democratic changes (Rueschemeyer, Stephens and Stephens, 1992; Boix and Stokes, 2003; Epstein et al., 2006; Vlfelder and Lustik, 2007). This is understandable. At present there is no universally recognised model, all existing theories have their advantages and shortcomings. In my opinion, the conclusions drawn by the first group sound more convincing. Having electoral rights guarantees that promises will be fulfilled (Baum and Lake, 2003). Democratic governments are interested in economic growth. Raising the standard of living of voters increases the chances of government officials being re-elected. Therefore people in power in democratic countries always seek to strongly support economic activity, raise employment levels and increase wages. Political competition also stimulates innovation (Wilke, 2002). If a government does not support progressive political or economic changes, competitors immediately take advantage of this. They accuse the government of incompetence, rigidity and ignoring the public interest. The government has to be responsive to any request from civil society, industrial corporations and individual entrepreneurs. Dictators primarily seek to maintain their position and their personal income (Lake and Baum, 2001). They must have a large army of officials and representatives of the security forces. This is why a significant portion of the state budget is spent on the army, the police and personal enrichment and not on economic development. A high level of economic and political regulation and the unlimited expansion of the powers of government structures give rise to corruption, which is a major obstacle for economic growth, especially in less developed countries (Drury, Krieckhaus and Lusztig, 2006).

The argument of the other group of economists, who believe that a certain level of economic development has to be reached in order for there to be democratic institutes, seems less convincing. Believing that only a person with a full stomach and money in their pockets is interested in their rights and freedoms is possible, but in order for lots of people to accept this view you need a very strong case. There may be a reasonable case in the future, but at present there is not. In order to defend the viewpoint of the second group of economists, the foundations of economic science have to undergo a thorough review. It is difficult to imagine that there are dictatorships capable of producing, investing, saving and sharing better than a free competitive market.

\subsection{Results of Research}

Let us discuss the results obtained by numerous researchers. Barro (1996) does not consider a democracy to be a key condition for growth. To a large extent, growth depends on the strengthening of legal order. Strict observance of laws and the fight against corruption radically 
improve the investment climate and boost economic activity. The dependency of economic growth on the index of democracy most likely rises and falls (Barro and Sala-i-Martin, 2004; Barro, 2012). When the index of democracy reaches a certain value, its effect changes from positive to negative. For countries in the transition from dictator regimes to democracies, the restoration of political rights and freedoms is essential for investment. When a moderate level of democracy is reached, redistributive processes begin in the interests of the majority and taxes increase, which has a negative effect on growth. Hall and Jones (1996) note a slightly positive link between democracy and growth. Sala-i-Martin (1997) is in agreement with them. Gerring et al. (2005) argue that democracy causes growth, but this does not happen at once, rather over a period of time. Over this period of time institutes are formed, rights of ownership are established, legal order is strengthened and funds are collected for investment. Views on the positive influence of democracy on growth are held by Feng (2003), Siegle, Weinstein and Halperin (2004) and Papaioannou and Siourounis (2008). Rodrik (1997) and Przeworski et al. (2000) do not see a direct link between the level of democracy and growth, but they do note the stability of growth in a democracy, the resistance of these economies to shocks and the high level of wages. They believe that it is the stability of development that allows developed democracies to achieve the economic leadership that they currently have.

Boix and Stokes (2003), Epstein et al. (2006), Rueschemeyer, Stephens and Stephens (1992) have a different perspective on the interaction between growth and democracy. They believe that a high level of economic growth causes democratic changes. A high standard of living will certainly lead to an increase in economic and political freedoms. A low standard of living is an insurmountable obstacle for the establishment of a democracy. Vlfelder and Lustik (2007) are not so categorical and they question the validity of such conclusions. In their opinion, economic growth facilitates democratization only in those countries that have a certain amount of successful experience in democratic transformations. Autocracies usually remain autocracies forever.

Acemoglu, Johnson and Yared (2008) express a pessimistic view on the link between growth and democracy. They believe that a high level of income has absolutely no influence on democratic sentiment. They believe that the analysis of the development of many countries over the last 100 and 500 years confirm these findings. Similar opinions are held by Przeworski et al. (2000), Levin and Renelt (1992) and Alesina et al. (1996). Welzel and Inglehart (2005, 2008) note the special role of cultural traditions, customs and the history of development of institutes in the establishment of democracies. The pursuit for democracy is not always linked to economic requirements, therefore one should not link growth with democracy. They are two different problems that need to be addressed separately.

The key findings to date are as follows. If there is indeed a positive link between democracy and growth, it is very weak. It is often the case that developing countries with low levels of economic and political freedoms have higher growth rates than developed democratic countries. How Europe, North America, Japan and two dozen other countries have managed to achieve such impressive economic success remains a mystery. Why was it that 200 years ago an industrial revolution took place in Europe, but not in China, for example? Why was Europe 
able to get out of the Malthusian trap first and why are some countries are still in its clutches? Let us try to answer these questions.

\section{The Model. Democracy, Profit and Economic Growth}

In order to understand the effect that institutes have on growth, first of all one has to look at the effect that institutes have on the profit of producers. At a microeconomic level it is far simpler to study the mechanisms of interaction between different economic parameters and identify connections between them. It is clear that the amount of profit of firms depends on the quality of institutes because laws, rights and freedoms determine the amount of transaction costs. Coase (1960) also argued that if transaction costs are not zero, the distribution of rights and economic efficiency depend on laws. Transaction costs are costs incurred by an entrepreneur in connection with their production activity. These costs include costs for electricity, equipment and lease of premises. Of course, the amount of profit depends on the amount of transaction costs. Consequently, the costs of product manufacturers depend on the quality of laws. Laws may reduce or increase transaction costs and these costs will have an effect on profit. With this approach it becomes quite clear that positive changes in freedoms must increase profits and a reduction in the level of freedom will cause profits to decrease. But profit is not economic growth. Economic growth is a change in GDP. Therefore we have to look in more detail at the link between profit and economic growth in order to understand the link between democracy and growth.

\subsection{Profit and Economic Growth}

Today there are few people who doubt the close link between economic growth and the profit of producers. The higher the growth in a country the higher, the profits will be. The lower the growth, the lower the profits will be. During crisis periods, when growth decreases to zero, profits rapidly disappear and difficult times begin for businesses and firms. Furthermore, there are also grounds to suppose that economic growth in a certain closed economy is exactly equal to the sum of profits (and losses with a minus sign) of all producers (Bilych, 2012). Let us imagine an economy where there is no money. It is a simple barter economy. How does profit occur under these circumstances and how can you get it? In order to gain profit you have to produce more of a product than was produced previously or you have to increase production as the result of an exchange. In a society such as this profit can only be materialized in the form of an additionally produced product. In a simple barter economy the words profit and economic growth are synonyms. If you add together all the profits and losses of manufacturers then the result will be exactly the same as the value of economic growth. A monetary economy creates a dense fog of the numerous complicated transfers of money and goods involved, inflation appears, as well as real and nominal values of economic indicators, but the equation between profit and growth still holds true. The price for factors of production is determined by the average marginal product. For those producers who use their resources efficiently, the marginal product will be higher than the average value. During the production process they earn profit. Companies where the marginal product is lower than the average incur losses. The sum of profits minus losses will equal the value of additionally produced products or, to put it another way, economic growth. 


\section{1l Macrothink}

Business and Economic Research

ISSN 2162-4860

2013, Vol. 3, No. 1

In the language of mathematics this may be summarised as follows. The production of a certain firm in stationary state may be represented by equation:

$$
p q=w l+r k
$$

where $q$ is the quantity of products produced by the enterprise, $p$ is the price of the product, $l$ is the number of workers at the enterprise, $w$ is the cost of labour, $r$ is the cost of capital and $k$ is the quantity of capital. The expenses (right-hand side of the equation) are equal to income (left-hand side of the equation), there is no profit. In order to gain profit, the firm has to obtain more products from the same amount of resources than before. This can be done by introducing new technology or improving the management of production processes. If this takes place, then after a period of time a company will increase production and receive a profit without altering its expenses:

$$
p q+\mathrm{d}(p q)=w l+r k+v,
$$

where $v$ is the company's profit for a $\mathrm{d} t$ period of time. Taking (1) into account, we get the following:

$$
\mathrm{d}(p q)=v .
$$

Growth in the production of a particular company is equal to the profits received thanks to effective and productive use of resources. After summing the output of all enterprises, we get the following for the economy as a whole:

$$
\mathrm{d}(p Q)=\sum v
$$

where $Q$ is the total products manufactured in the country. The last equation confirms that economic growth is equal to total producer profits (further information on this in: Bilych, 2012).

\subsection{Democratic Changes and Economic Growth}

Let us suppose that in a certain country members of the government approved laws on the licensing of certain types of activity, prohibited the free exchange of currency, abolished the free purchase and sale of land and increased taxes. How will this affect the activity of firms? Will their profit change? How will this affect economic growth? In a world where there are transaction costs equation (1) will look different. An entrepreneur will have additional costs. $\mathrm{He}$ or she will need to hire less workers and (or) pay them a lower wage and also purchase less capital equipment than if they were living in a world with zero transaction costs. On the right-hand side of equation (1) there is another term linked with costs for obtaining licences, currency exchange, legal recognition of ownership and payment of additional taxes. Therefore equation (1) will be as follows:

$$
p q=w l+r k+c,
$$

where $c$ is transaction costs. After transforming the equation we will have:

$$
\mathrm{d}(p Q)-\mathrm{d} c=\sum v .
$$


If the laws and institutes in a country do not change at all then $\mathrm{d} c=0$, and equation (3) will be no different to equation (2). Consequently any technological and (or) managerial innovations will result in absolutely identical profit rates both in democratic countries and in dictatorships, if there are no institutional changes. This conclusion is confirmed by numerous well-known facts. In poorer countries where it would seem they have an advantage of low rates of payment for labour, profit rates are the same as an richer countries. Clark (2007) gives interesting results of the work of the cotton industry in certain countries at the beginning of the $20^{\text {th }}$ Century. At the beginning of the century, entrepreneurs from India, China and other poor countries were able to purchase and they purchased machines and equipment in England at prices that were normal at the time. Taking transport expenses into account, the equipment for the factories was more expensive for them than for entrepreneurs in England and France. However they had a great advantage due to the low wages paid to staff. A simple calculation demonstrated that in 1910 , profit rates of companies in the cotton industry in India should have been in the range of $19 \%$ to $23 \%$, in China from $22 \%$ to $33 \%$. At the same time, the profit rate in England was $8 \%$. However, in actual fact there was no difference between the profit rates in factories in England, China or India. Clark attempts to explain this surprising fact by the low level of efficiency of the workforce in poor countries, but he himself believes this explanation to be insufficient. Servicing the machine at the factory did not require much training or advanced qualifications, therefore it is difficult to link low profits exclusively with a low level of efficiency of workers. Now, however, given the above, we can give a simple explanation for the situation. The low value of the workforce in India and China was more than compensated for by the high transaction costs of doing business in those countries. It is impossible to say how much entrepreneurs had to pay various officials and what it cost to obtain the various permits, but the fact that in India and China these expenses were much higher than in England should not raise any doubts.

If there are no democratic changes then it follows from equation (3) that a poor and a rich country grow at the same rate. This rate is determined by technological and scientific progress. Of course, the difference in standards of living only increases because $3 \%$ of 100 is 3 and $3 \%$ of 1000 is 30. If one day all countries became developed democracies, economic growth in poor countries would immediately speed up. This would happen due to a reduction in transaction costs. Poor countries would rapidly being to reach the same level of economic development as in rich countries. After some time the growth in these countries would slow down and when the level of income of citizens became equal, the growth in all of these countries would be the same. For the moment, however, dreams are still dreams. This is not how things are happening today. Wireless voice and video communication technology from Skype is reducing the cost of holding negotiations, it provides instantaneous communication, improves the management of companies and reduces transport costs. Suppose that in the US where transaction costs are low, Skype technology lowers economic costs by $2 \%$ over a certain period of time. Consequently, companies' profits increase $2 \%$ and the additional economic growth is also $2 \%$. In Nigeria, by no means all of the population has Internet access. Therefore, new technology will only be implemented in large cities and even there it will mainly be used only in order to reduce costs for international and intercity negotiations. This means that profits and economic growth will only increase slightly, perhaps by $0.5 \%$. It is most likely that local officials with corruption 
interests in branches of traditional means of communication will take certain steps to protect their income. There will be decrees, permits and new laws that will make implementing innovation much more difficult. It may indeed be the case that the actions of officials will enable tariffs to be raised for the services of ordinary telephone companies. These actions will increase the costs of all companies, let us suppose by $1 \%$ on average. As a result, the real income of citizens in Nigeria will decrease $0.5 \%$. In Botswana events may take a different turn. The country's government, aware of the importance for national producers and the general public of a cheaper form of communication, will take measures to improve the economic climate on the communications service market. The procedures for the registration of new companies may be made simpler, taxes lowered, licences withdrawn. Of course, these measures will not be able to reduce transaction costs to the level of the most developed countries, but they will significantly increase the profits of many companies. This will result in the overall transaction costs in the country decreasing 4\%. As Skype technology enables labour productivity to be increased by $2 \%$, the overall economic growth in Botswana will be $6 \%$ and the country will be higher than the US in terms of this indicator. This means that between Botswana and the US there will be a so-called economic convergence (Barro and Sala-i-Martin, 2004). The difference between the levels of economic development and per capita income in these countries will decrease. The difference between per capita incomes in the US and Nigeria and also in Botswana and Nigeria will increase. The levels of economic development of the countries depend, to a large extent, on the amount of transaction costs and the size of economic growth depends on the size of the decrease in transaction costs. If at any moment in time transaction costs disappeared, all the global economies would demonstrate absolute convergence, the incomes of all the people on the planet would be the same. A reduction in transaction costs of exchange is a key factor for successful development.

The amount of transaction costs depends on two factors; the level of development of science and technology and also the quality of institutes. As everybody has free access to technologies and scientific achievements in the modern world, the only variable that defines the difference in transaction costs in different countries is the quality of institutes. Institutional changes immediately bring about a change in the amount of transaction costs, which in turn affects profit and a change in profit changes the amount of economic growth.

A few words on taxes. Let us very briefly discuss their effect on economic growth and the level of democracy. There is no doubt that taxes increase transaction costs and reduce growth. A portion of economic exchanges are not carried out simply because taxes that should be paid after a transaction is carried out are higher than the benefits. Therefore entrepreneurs lose a portion of profit and the economy does not develop as fast as it could. The negative dependency between the amount of tax and economic growth is well known (for example: Barro and Sala-i-Martin, 2004), therefore there are no longer disputes in this regard. What is interesting is whether or not taxes have any effect on the level of democracy? My answer is yes. Taxes can have a big impact on the voting process and distort the final result. Many effective solutions may be rejected. As part of the profit goes to the budget the most economically active portion of the electorate lose an important argument of influence over other voters. Having lost part of their profit they are not able to compensate for the losses to certain voters who may have 


\section{Macrothink}

Business and Economic Research

ISSN 2162-4860

2013, Vol. 3, No. 1

the casting vote. The final result of voting will be completely different than if there were no taxes. Therefore, taxes increase the likelihood of adopting ineffective laws and they greatly limit freedom of choice. Taxes have a negative effect on the level of freedom and democracy.

\section{Data and Empirical Results}

A big problem in studying the link between the level of democracy and economic growth is the short period of observing changes in the levels of democracy in different countries. Just 30 years ago regular publications of ratings and indexes began to appear that reflected the quality of institutes and laws. Such a short period of time is obviously not enough for an in-depth and serious study of institutional changes. Institutes of developed democracies were formed over hundreds of years; they evolved gradually. There were delays along the way and there were setbacks. There were also, of course, revolutions that radically changed laws and the whole structure of society. But on the whole it was a slow and steady journey forward by method of trial and error. Institutes cannot be planned; the overall scheme of institutes does not mature in someone's mind (Schneider, 1963). And still, over the last 30 years there have been major changes in many countries of the world. The collapse of communist regimes in Europe provoked political changes throughout the world. Deprived of support, many dictatorships crumbled. The world rapidly began to change; institutes also began to quickly change. Therefore, today we have a unique historical opportunity to study the influence of institutes on growth which must be used.

\subsection{Comparison of the Figures of Different Countries}

The Index of Economic Freedom (The Heritage Foundation and the Wall Street Journal) began to be published regularly a relatively short time ago, starting in 1995 . Every country is given an index in the range of 0 to 100. In 2012 North Korea was given the lowest index -1.5 . Hong Kong and Singapore have the highest indexes -89.3 and 88.0 respectively. For the purposes of this study the change in the level of economic freedoms was calculated as the difference between the indexes in 2012 and the indexes in 1995. If in 1995 there was no index for a particular country then the difference between the index for 2012 and the index of the earliest year of observation was used. Economic growth was calculated as the arithmetic mean for the entire period of observations. Growth figures were taken from data from the International Monetary Fund. The relationship between the change in the index and economic growth is shown in figure 1. 


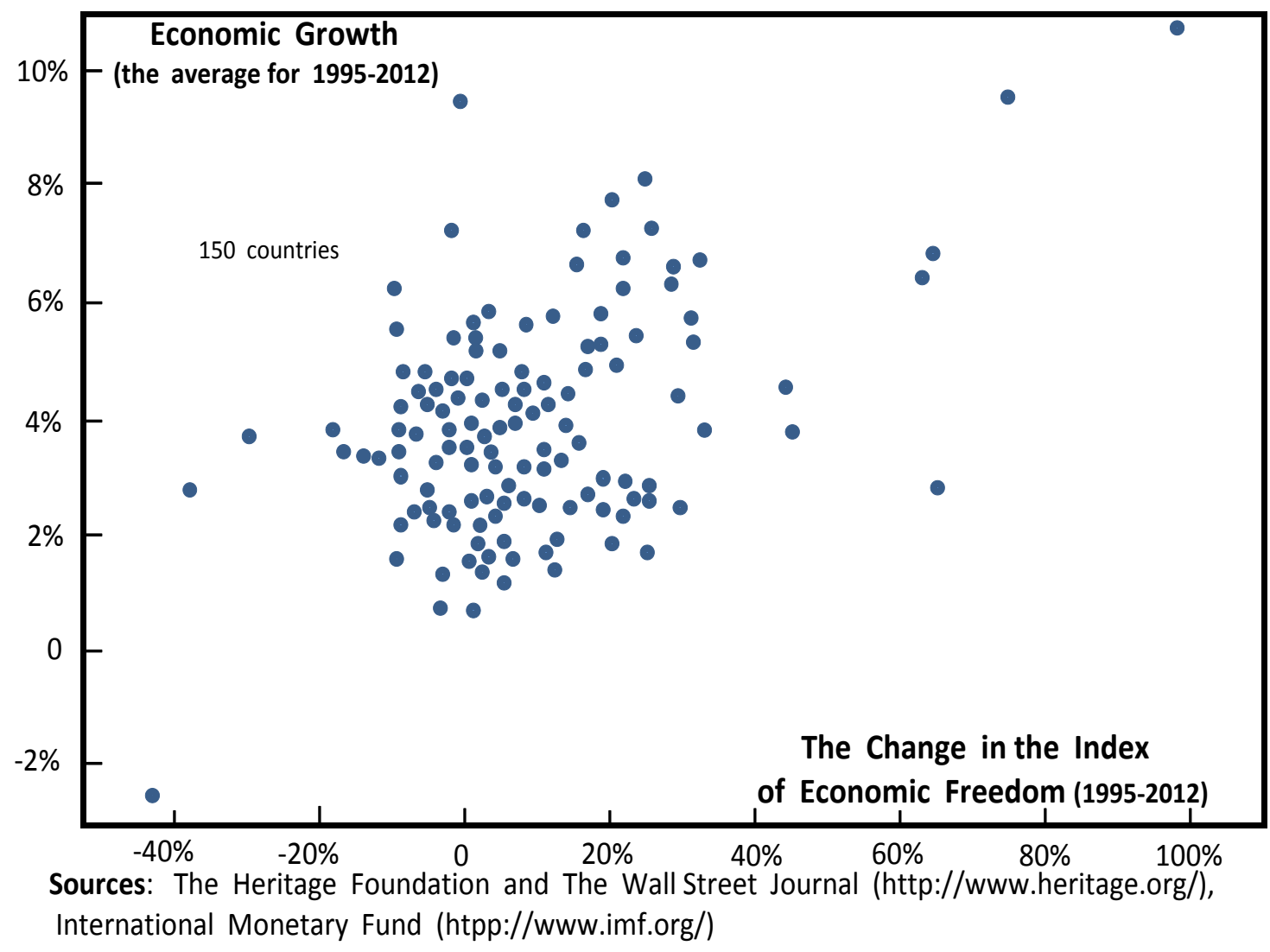

Figure 1. Relationship between the change in the Index of Economic Freedom and Economic Growth

For such a short period of observations the result seems quite optimistic. Economic growth in countries with the greatest positive changes to the index is higher than the growth in countries where there was a reduction in the index. Countries with only a slight change in the level of economic freedoms demonstrate a rather large range of growth values. The exceptions to the general rule are countries with oil reserves and China, which we will talk about later. A high level of economic growth in countries that extract oil is generally caused by an increase in price for this raw material over the past decade. Many researchers do now take the results of these countries into account when discussing issues associated with studying the causes of economic growth. In my opinion it is not worth doing that. Over a relatively long period of observation, the effect of changes in the cost of a raw material on the results of studies disappears because, as the history of economics teaches us, prices for raw materials in the long-term always tend to decrease. Unfortunately, our period of observations coincided with a period of high demand for energy and instability in the Middle East. The large variation in figures for the growth in countries with the same or similar index changes is primarily linked to the inevitable subjectivity of assessing the level of freedom. Furthermore, institutional changes that took place before 1995 were not taken into account at all. Changes such as these undoubtedly play a role because they may have a very long-lasting effect. The result obtained can be evaluated in different ways. For some it may serve as proof of assumptions made, for others it means absolutely nothing. But we have a wonderful opportunity to infinitely extend the period of 
observations and a result such as this will be much more difficult to dispute. It is very easy to do if we proceed from the assumption that many thousands of years ago all countries began their development with identical and very low levels of material well-being and freedom. In this case, today's income per capita is equivalent to the value of economic growth for several thousand years. Today's level of democracy or economic freedom may be considered the difference between today's level and the level from the distant past. The difference between today's figure and zero is equivalent to today's figure. Therefore the graph of the relationship between the index of economic freedom in 2012 and the GDP per capita value, which is shown in figure 2 , is in fact the graph of the relationship between economic growth and the change in the level of democracy. This depiction of the relationship can convince even the most resolute pessimist that the arguments are valid. This is the very link that Lipset noted 50 years ago. He, of course, thought that it was a link between income and the level of democracy. But it is no less justified to believe that it is a link between economic growth and democratic changes that have taken place over the entire period of human history.

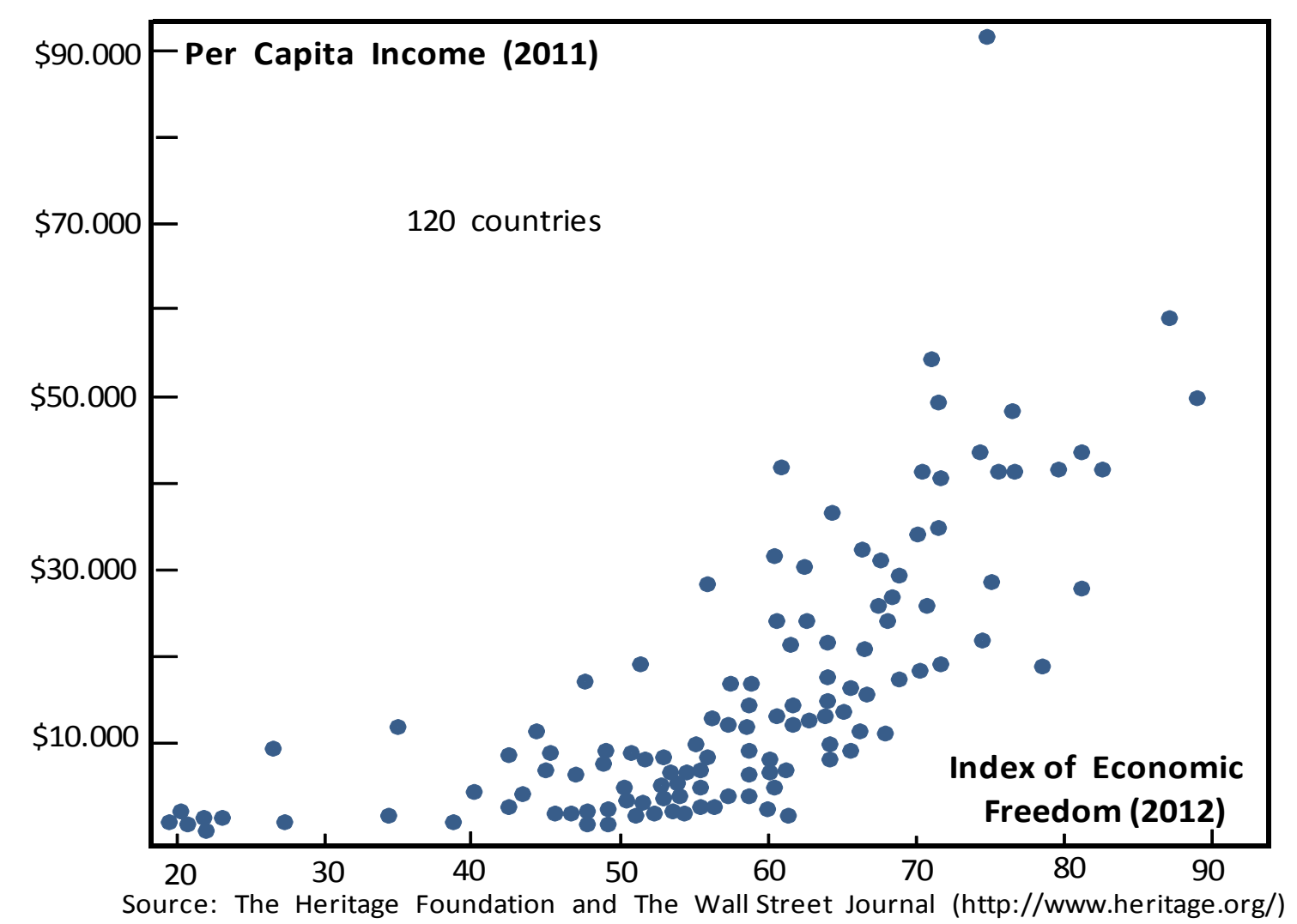

Figure 2. Relationship between the Index of Economic Freedom and GDP per capita.

\subsection{Analysis of a Country}

It is not possible to avoid subjectivity when assessing the level of development of democratic institutes, but it is possible to reduce its effects. Laws and institutes in all countries have their own features that are closely linked to the cultural and historical past of the people in these countries. For example, everybody knows the differences between common law which developed in England and civil law created from Roman law. The laws of certain countries, 
including former English colonies, are influenced by common law. The laws of many European countries are created on the basis of Roman law (Coffee, 1999; Johnson, 2000). Which institutes are better for economic development? Which are the most democratic? Disputes regarding this issue have been going on for a long time, but it is still early to draw definitive conclusions. Also, religious beliefs play a significant role in the formation and development of institutes. Institutes of the church in many countries have close ties with state institutes. What effect does this have on laws and freedoms? How do Judaism, Christianity, Islam and other religions affect the formation of civil institutes? Sometimes it is difficult for an outside observer to assess the role of different institutes in the life of a country and their influence on the level of freedoms. Therefore, for a more objective evaluation of the quality of institutes we should try to analyse the development of a particular country. Of course, it is not possible to entirely avoid subjectivity, but it is simpler to follow the democratic changes over time in one country rather than compare the changes between countries. As a value for democracy I used data published from the beginning of the 1970's by the organisation Freedom House. Their evaluation of institutes consists of the evaluation of two parameters, political rights and civil freedoms. Each of these parameters is given an index from 1 to 7 . The higher the quality of institutes, the lower the index. In my opinion, the simple arithmetic sum of these indexes fully reflects the overall level of democracy in a country. Therefore, this is the approach that was used for analysis. The difference between economic growth in the country under review and the economic growth in the US was used as a value of growth for the country. This was therefore an attempt to avoid the effect of global economic ups and downs in the result. In order to smooth out the growth curve the economic growth in a particular year was calculated as the average value over the last three years. The countries were chosen practically at random for analysis. The only requirement was to have at least minimal changes in the level of democracy. Figure 3 and Figure 4 present the results for 16 countries. 

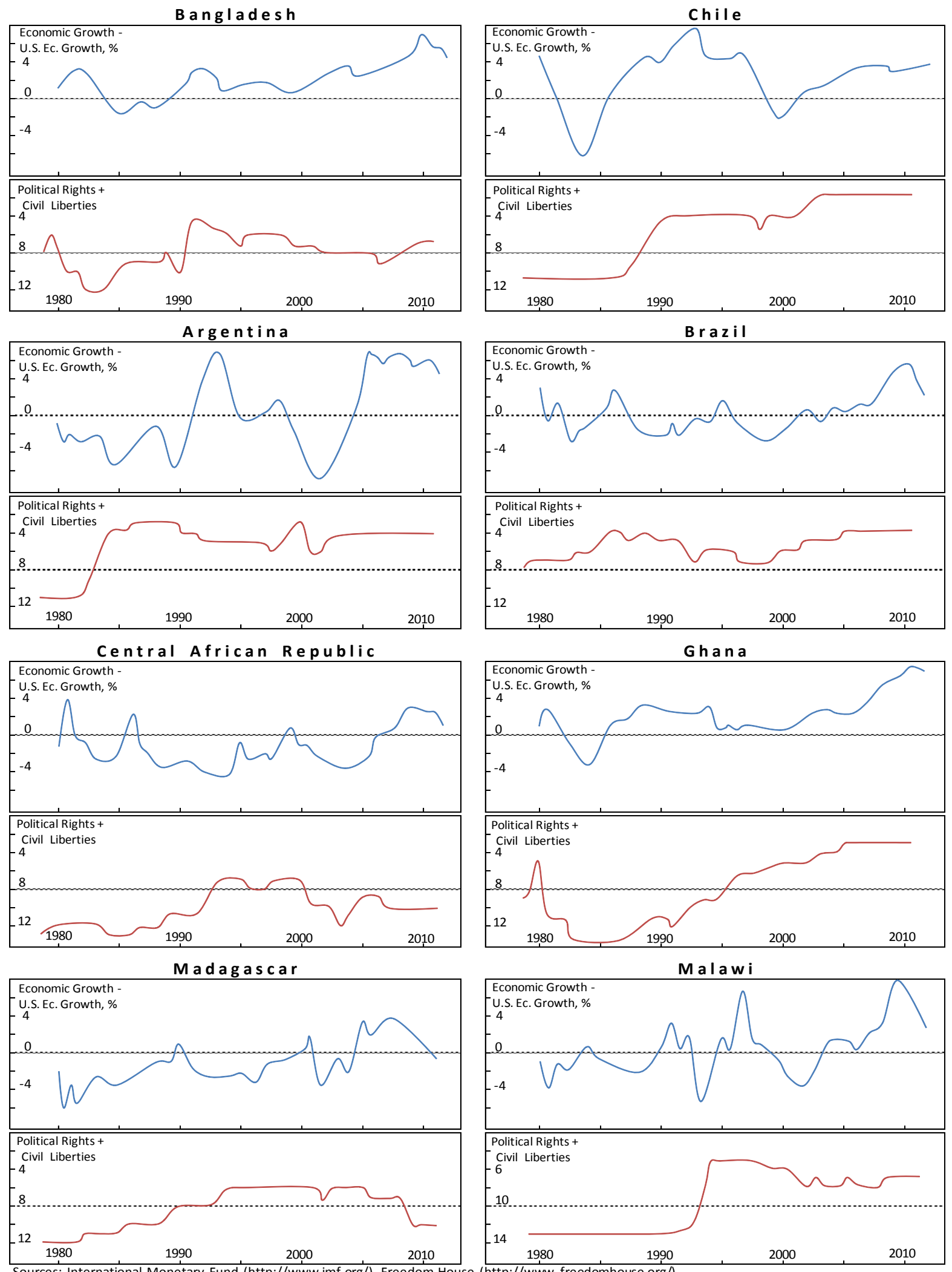

Figure 3. Economic growth (from 1980 to 2012), political rights and civil freedoms (from 1978 to 2011) 

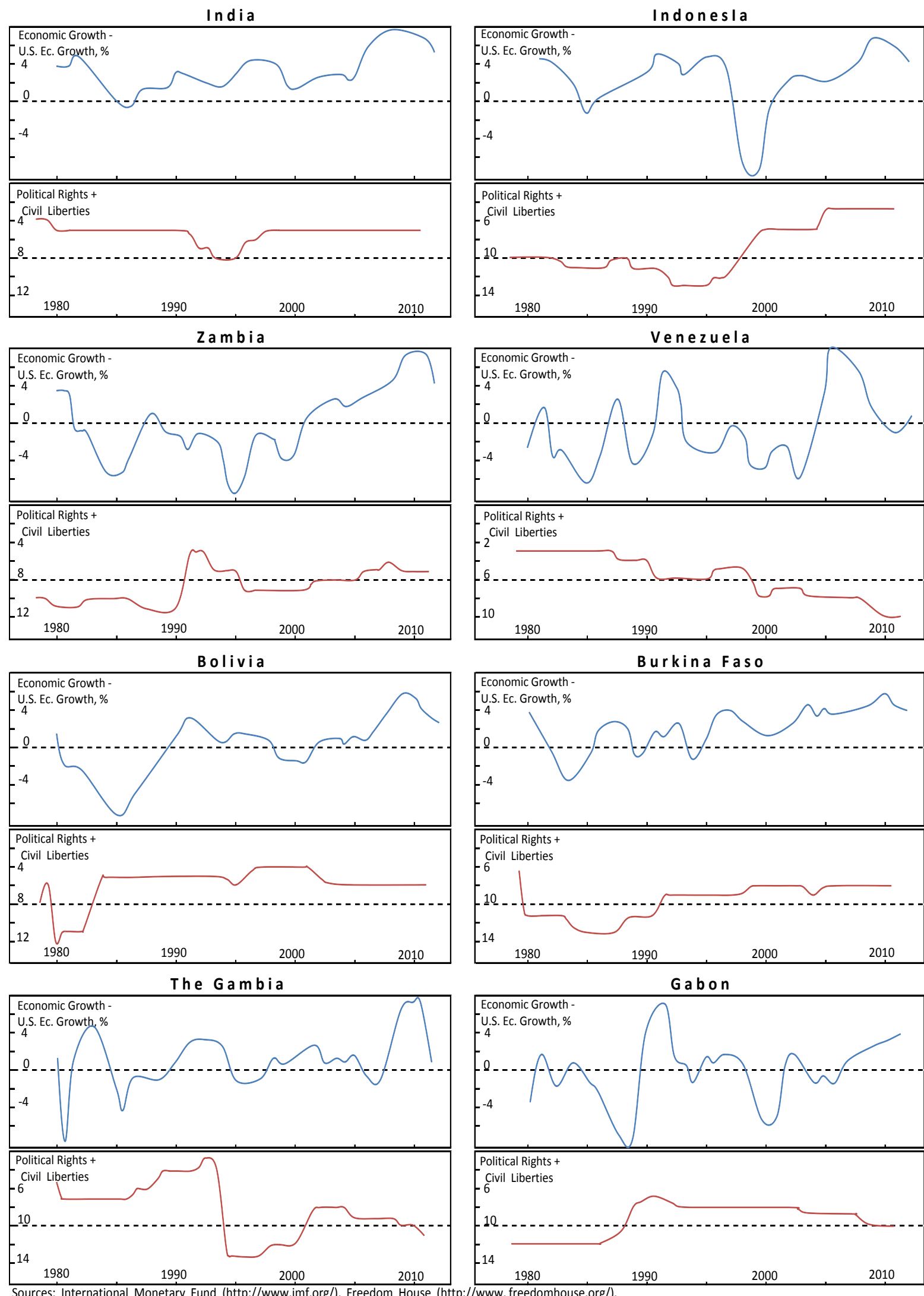

Figure 4. Economic growth (from 1980 to 2012), political rights and civil freedoms (from 1978 to 2011) 


\section{Macrothink}

Business and Economic Research ISSN 2162-4860 2013, Vol. 3, No. 1

On the whole I believe that the results support the assumptions made earlier about the link between democratic changes and growth. An improvement in the situation with political rights and civil freedoms usually leads to an increase in economic growth. A decrease in freedoms leads to a decrease in growth. If there is a significant decrease in freedoms, growth moves to the negative value zone where the rates of economic growth are less than US rates. Indicators of growth and democracy do not always change at the same time. This evidently has to do with the fact that the formation and stable functioning of institutes requires time. Aside from this, a certain level of subjectivity of indexes of rights and freedoms is reflected in the result and it is not possible to entirely avoid this.

A decrease in the democracy index in Bangladesh since 1979 is causing a reduction in growth from 1982, growth in 1984 is moving into the negative zone. From 1984 to 1992 there was a considerable improvement in the situation with rights and freedoms. Starting from 1985, the economic situation began to improve and after 1989 economic growth in the country began to exceed growth in the US. The slow reduction of the democracy index after 1992 reduced the economic growth in 1999 almost to zero. However, after 2007 when the index began to increase, economic growth was consistently higher than $3 \%$.

In Chile the sum of indexes of rights and freedoms before 1987 was at a very low level (11 units). Starting from 1982, economic growth moved to the negative region and reached a minimum in 1984. From 1987 onwards, democratic reforms began in the country and ended at the beginning of the 2000s, when the democracy index reached its highest value (2 units). Growth moved to the positive region reaching a maximum in 1993. The growth maximum was reached after a very rapid increase in the democracy index in 1987-1990.

Political and economic reforms began in Argentina in 1983. The democracy index very quickly rose from 11 to 5-3 and at present it is 4. Growth before 1991 remained negative and then moved to the positive region. After a slight reduction in the level of democracy, growth became negative in 1995-1996 and in 1999-2003. After 2005, economic growth was consistently high around 5\%-6\%.

The curves of the level of democracy and growth in Brazil are surprisingly similar. A strengthening of democracy almost always coincides with an increase in economic growth and a reduction in the level of democracy always causes a decline in growth. The maximums and minimums of one indicator coincide with the maximums and minimums of the other indicator.

For the Central African Republic the behaviour of the growth curve looks quite understandable, except for the period from 1989-1993. A big increase in the indicators of freedom did not cause the same increase in growth for that period. Growth increased slightly, but nevertheless remained in the negative zone until 1999.

The curves for Ghana are ideal for confirming the assumptions made regarding the link between democratic changes and economic growth. From 1991 to 2005, the democracy index increased from 12 to 3 . Changes such as these of course caused a rapid growth in the economy, which reached $8 \%$ in 2011. 
For Madagascar the economic indicators of the 1990's look slightly strange against the rapid growth of freedoms up until 1993 and the high level of economic growth after 2004.

The economic growth of Malawi corresponds to democracy indicators, except for the period from 1989-1991 when growth moved to the positive area and the democracy index remained consistently low.

A reduction in the rights and freedoms in India in 1990-1993 caused a reduction in growth figures from $3.5 \%$ to $1.5 \%$. An increase in the democracy index in 1995-1998 led to consistently high figures for the growth of GDP after the year 2000.

The development of Indonesia generally confirms the link between the change in democracy and economic growth, except for the short period of deep decline in growth, most likely due to the Asian crisis.

Figures for Zambia are also easily explained. The only question is to do with the moderate increase in growth in 1991-1993 after a dramatic increase in the level of democracy from 11 to 5 .

The weakening of the democratic institutes in Venezuela caused a gradual reduction in growth. The economic recovery of the second half of the 2000s is undoubtedly linked with high global prices for oil.

The nature of changes in economic growth in Bolivia, Burkina Faso, The Gambia and Gabon do not contradict the assumptions made. The only surprising thing is the considerable economic growth in these countries after 2005.

The following conclusion should be drawn. There is rather a lot of evidence confirming the positive link between democratic changes and economic growth. There are very few exceptions. It must, of course, be admitted that the period of observations is not long enough for a qualitative analysis. However, in my opinion it is a step in the right direction. In the future, when the period of observations is significantly greater, we will be able to draw definitive conclusions.

\subsection{Industrial Revolution, Acceleration of Growth and Decline in Birth Rate}

In 1800 , the average person did not live any better than in 100,000 BC (Clark, 2007). Life expectancy was no longer than with the hunters and gatherers: $30-35$ years. The rate of technical progress in $10,000 \mathrm{BC}$ was $0.001 \%$, in $1 \mathrm{BC}$ it was $0.009 \%$, in $1000 \mathrm{AD}$ it was $0.001 \%$, in $1500 \mathrm{AD}$ it was $0.02 \%$ and in $1750 \mathrm{AD}$ it was $0.045 \%$. The Earth's population also increased at a slow pace: in $1 \mathrm{AD}$ on the entire planet there were 300 million people, in 1000 AD there were 310 million people, in $1500 \mathrm{AD}$ there were 490 million and in $1750 \mathrm{AD}$ there were 770 million (Durand, 1977). Any increase in labour productivity actually only led to an increase in the population, the real standard of living remained unchanged. The standard of living of poor social groups was only above the minimum subsistence level in periods following wars and mass epidemics. However, at the turn of the $18^{\text {th }}$ and $19^{\text {th }}$ centuries something changed radically. Economic growth increased 10-50 times. The increase in the population began to give way to the growth in labour productivity. Furthermore, after a certain 
period of time the birth rate began to decline dramatically. The incomes of all social groups began to increase. Of course, these changes did not happen in all countries, many regions of the world continue to be in the Malthusian era. The increase in production in these regions is still offset by a high birth rate. In the early $19^{\text {th }}$ century the great discrepancy between populations began; some countries rapidly became wealthier and others hovered around the same place. What happened 200 years ago? What were the causes of the dramatic increase in the growth rate? Why were there winners and losers? The first signs of the approaching changes undoubtedly appeared long before the industrial revolution. Scientific discoveries and technological innovations appeared in the $16^{\text {th }}, 17^{\text {th }}$ and $18^{\text {th }}$ centuries. However, this process suddenly began to rapidly speed up. People of different social classes and beliefs became interested in new knowledge; they felt the need to gain an education. Schools and universities appeared, the number of books published greatly increased, periodicals began to be published. Mokyr (2002) states that the industrial revolution was caused by a significant improvement in access to new knowledge. It is difficult not to agree with this conclusion. But the question arises, why did this happen in England in particular? Why was it that it was this little island that was able to get out of the Malthusian trap first? Why did this not happen in China, Japan or somewhere in Africa? Is a rapid increase in knowledge not a consequence rather than a cause of global changes?

If we look at the events of those times through the eyes of a modern economist, then first of all our attention will be drawn to the unprecedented consolidation and expansion of the rights of private ownership and also the rapid development of the system of free entrepreneurship in Western Europe. The expansion of economic rights led to an expansion of political rights. The strengthening of democratic institutes significantly reduced transaction costs of exchange. Due to these changes, economic growth in Europe dramatically increased. This is when the great discrepancy between populations began. Some countries began to develop quickly and others continued to tread water in the same place. This changed the history of humanity forever. We began to see countries that were leaders and countries that lagged behind. The main cause of the great discrepancy was the difference in the levels of democratic changes.

Let us briefly discuss the reasons why private ownership emerged. One thousand years ago private ownership of land was not possible. There were good economic reasons for this. A lone peasant or peasant family could only work a small area of land. The level of development of technology did not allow people to obtain a profit from the land that would be sufficient to protect their land plot from the encroachments of others. In other words, transaction costs of land ownership were greater than the benefits from its use. Therefore the main owners of land were pharaohs, kings, czars and major feudal lords. They owned large territories, the income from which enabled them to maintain large armed forces to protect them from external and internal enemies. Peasants, who were obliged to offer their labour in exchange, also benefitted from this protection. Feudal institutes such as serfdom were an effective contract between serfs and landowners (North and Thomas, 1973). Protection was obtained in exchange for the labour of serfs on the landowner's land. Over time labour productivity increased, means of production improved, the quality of seeds improved and new technologies arrived to work the land. Also, transaction costs of exchange steadily decreased. The first town and village markets appeared, 
roads were built, laws were made and things became safer. Then one fine day a landowner discovered that it was much more profitable to lease their land or sell it, rather than maintaining a large army of supervisors and managers. This was beneficial both to the landowner and to the peasant; they both received greater profits from this. This is how private ownership began. The growing class of owners demanded that their rights be strengthened, they needed new laws. The authorities were not especially opposed to such changes and private ownership very quickly received legislative recognition. But in order to strengthen economic rights, an expansion of political rights is required, which inevitably leads to the establishment of democratic institutes.

We have come to a very important issue. Why was it that Western Europe reached such a high level of labour productivity and such a low level of transaction costs faster than the rest of the world? My answer has to do with a higher level of competition. Europe was rather densely populated and there were a number of independent states in a limited space. Of course, political influence primarily depended on economic power. The amount of income of a king or feudal lord had an influence on the size of his army and the quality of weapons. In a war, the richest monarch always won, their army had the advantage. Within a country the wealthiest feudal lord was usually the most influential and sometimes even rivalled the king. The higher the competition, the more effective production is. China or Japan did not experience significant external pressure, therefore they were able to develop slowly. Countries in Europe were not able to do this; they faced strong competition from their neighbours. Weakness meant immediate loss of independence. Africa never had such fierce competition. The rulers of Ancient Egypt were more concerned about the power of European countries than the armies of their own neighbours.

Competition explains a lot, but it does not help us to understand the causes of the explosive growth in labour productivity in the $19^{\text {th }}$ century. Why did growth increase from thousandths or hundredths of a percent to one percent or even higher? In my opinion it is all to do with the arrival of institutes of private ownership, which considerably increased the number of small, medium and large enterprises. The free entrepreneur came onto the scene. Practically any citizen could freely be engaged in self-employment. From that moment they were able to choose, they had the chance to independently organise production or engage in hired labour. The choice was ultimately determined by the person's ability, knowledge and expected income. How did this affect economic growth? In the time of feudal relations a worker was fully or partially dependent on their master because they received a reward equal to the minimum subsistence level. The worker was the means of production or a portion of the capital belonging to the feudal lord. The feudal lord used the worker to earn profit and increase their wealth. Peasants who were not free had no chance to earn profit. Let us suppose that a feudal lord received a profit of $5 \%$ per year. This means that his income increased every year by $5 \%$. However, the income of the workers who depended on him did not change at all. In order to evaluate the increase in GDP of a country where a feudal lord lived you have to divide the profit or the additional income of a feudal lord by the number of workers and their family members. If a feudal lord had on average 1000 people, for example, then the growth in GDP or, in other words, the economic growth in that case would be $0.005 \%$. The free market system 
gave thousands of people freedom and they all rushed to increase their wealth and earn profit. In order to do so they needed knowledge. Now it is clear that the dramatic increase in scientific discoveries and technical innovations was a consequence and not a cause of change. Knowledge creates innovation and innovation creates profit. If the profit of every free citizen was $5 \%$ then economic growth in a country would also be $5 \%$.

Taking this into consideration it is not at all difficult to understand the reasons why the Malthusian curse disappeared and the birth rate declined in developed countries. A peasant who depends on their master is interested in increasing the size of their family. The smallest increase in income will lead to a rise in the birth rate because a new family member is able to increase the family's overall income in the future. Since wages are set by the master and do not usually depend much on knowledge and skill, a peasant family was in no way interested in reducing the birth rate. But when a peasant or worker becomes free, everything rapidly changes. In order to succeed in market conditions you need a good education, which requires a considerable amount of funds. Furthermore, the personal income of an entrepreneur or employee is largely dependent on the size of their family. From a certain time in history, the size of a family began to depend not on the minimum subsistence level, but on the current and future profit of the family members.

The main conclusion to be drawn from this is that economic development led to an increase in labour productivity and a decrease in transaction costs, which brought about democratic changes. Democratic changes led to the arrival of the free competitive market, which, in turn, contributed to the further growth of the economy.

\subsection{Economic Growth in China}

Many researchers are surprised by the fantastic growth of the economy in China; the country's GDP has been increasing, on average, more than $9 \%$ each year for the last thirty years. There have been various attempts to explain China's success. Some economists associate the rapid growth of the economy with the effectiveness of state institutes (Liew, 2001), others note the importance of capital investments (Hu and Khan, 1997) and others point to the particular features of the development of formal and informal institutes (Yao and Yueh, 2009). It is difficult to dispute such conclusions, but I believe that there is another reason for the Chinese miracle. Consciously or unconsciously, since 1978 the Chinese leadership has been attempting to follow the route of Singapore. This route implies a certain restriction on political rights in exchange for full economic freedom. If we look at a democracy as a sum of political rights and economic freedoms, then today's increase in production in China should not come as a surprise. After the periods of the Great Leap Forward and the Cultural Revolution, starting from 1978, there was a phenomenal increase in economic freedom. This Great Leap Forward is what explains the high economic growth in the country. Just over forty years ago, all life in China depended on one person, the ideas of Mao were thought to be a holy scripture by every Chinese person; doubters faced death. This is why one should not underestimate the changes that took place at the end of the 1970's. The current indexes of political and furthermore economic freedoms in no way reflect these changes. The freedom of entrepreneurial activity, the freedom of movement and the freedom of foreign economic trade completely changed the business 
atmosphere in the country. There is nothing surprising about the current growth in China. Another issue is far more interesting: how long will the rapid growth of the country's economy continue? Are political rights really that important for economic development? Is it possible that in the future there will be many countries that are not free in a political sense, but whose citizens have very high incomes? I will try to answer these questions.

Qatar, Singapore and the United Arab Emirates have a very high GDP per capita and they are among the top ten countries in terms of this indicator. It has already been mentioned above that countries where the wealth is linked to oil and gas extraction do not develop in a consistent manner. The age of traditional sources of energy will one day come to an end and these countries will have to change their development strategy. Indeed, many governments in these countries are already taking certain necessary steps. As demonstrated by Singapore, economic freedom is a necessary condition for successful development. However, I am certain that this condition is not enough and Singapore's future is not as rosy as it might seem. Let me explain. The lack of political rights in the country is offset today by a higher level of economic freedom. Furthermore, the very high tax rates in developed countries create additional advantages for Singapore. The amount of taxes has a negative effect on economic growth (for example: Barro and Sala-i-Martin, 2004). Taxes directly affect the level of economic freedom. If under a specious excuse somebody takes away a considerable portion of your salary then this means that your rights and freedoms are restricted. Your rights and freedoms depend on the government's appetite and it usually has no problems with its appetite. Economic growth in developed countries is largely maintained by high taxes. This cannot go on infinitely; the growth of governments through the doubtful ideas of Keynes will one day come to an end. On the contrary the leadership of Singapore may get carried away with these ideas and raise taxes, of course in the sincere hope of improving the standard of living of its citizens. In countries such as these, a great deal depends on the opinions and ideological beliefs of leaders. And in the future this may become a serious problem. If Singapore loses its leadership in terms of the level of economic freedom, it will inevitably begin to fall behind the leading countries in terms of economic development. We have now come to a very important issue. Why are political rights so important?

Voting allows you to make decisions that benefit the majority. If you are interested in the economy and not in the colour of building façades then this means that a decision will bring profit to the majority. In order to adopt a law the majority can compensate losses and the minority will not object. Otherwise, if the losses are greater than the profit then the minority may buy the votes of the majority. Something similar is constantly occurring in politics albeit in a slightly different form. In any case, voting allows you to make decisions that bring the maximum profit. Since economic growth is equal to the total profit, voting is an important condition for successful economic development. Therefore it is not only economic freedoms that are important; political rights also play a big role. In other words, only democracy was able to provide the maximum level of production of goods and services.

\section{Conclusions}




\section{Mll Macrothink}

Business and Economic Research

ISSN 2162-4860

2013, Vol. 3, No. 1

The relationship between the level of democracy and the income of the population which Lipset noted more than 50 years ago prompted many researchers to look hard for a link between the level of democracy and economic growth. However, it turned out that economic growth does not at all depend on or, in the opinion of some economists, is weakly dependent upon the level of democracy. This conclusion surprised many. We know of many non-democratic countries where the economy is growing faster than the economy in developed countries. Of course, this result is disappointing because at first glance it contradicts the fundamentals of economic science. It is difficult to come to terms with the idea that dictators may sometimes create effective institutes and a free competitive market is not always the best economic solution. However, we should not jump to conclusions. When a result contradicts the fundamentals of science this does not mean that we should put an end to this science. Perhaps the objective was not formulated correctly or an obvious error is hidden within the reasoning. I believe that a similar thing has happened in this case. The well-known link between democracy and income may be explained by the positive link between democratic changes and economic growth. This becomes obvious if you bear in mind that today's levels of income and democracy are the difference between today's level and the level one thousand years ago. The difference between a certain number and zero is equal to that number. Therefore we should look for a positive link between democratic changes and economic growth. Furthermore, I do not believe that this assumption has a solid theoretical base.

Coase argues that the effectiveness of the distribution of rights does not depend on institutes only in a world with zero transaction costs. In the real world institutes are important. The amount of transaction costs, which are costs for all of us, depend on the level of political rights and economic freedom. The level of production of goods and services in any given country depends on the amount of these costs. The higher the costs, the lower the level of production. In a dictatorship, the standard of living is always lower than in a democracy. However, profits and economic growth depend not on the absolute level of transaction costs, but rather their changes. If transaction costs are constant, profits of producers and economic growth in democratic countries and dictatorships are exactly the same. Profits and growth depend only on the changes in costs for the production of a certain amount of products. Therefore, if transaction costs are constant, profits and growth are only defined by the level of scientific and technological progress. The level of progress enables costs for the production of one unit of a product to be reduced by the same value in any society. Changing a horse for a tractor increases the productivity of labour both in England and in Zambia. However, Zambia has many more opportunities to increase its economic growth. The costs for producing products in a country such as this could be significantly reduced not only through innovation, but also by reducing transaction costs. Zambia has many more opportunities to reduce transaction costs than England. The expansion of economic and political freedom will reduce the costs for everybody living in the country. Consequently, the profit of each resident will increase, which will have an effect on the level of economic growth. Profit and growth are closely linked to one another; they are synonyms. The total profit in a closed economic system is exactly equal to economic growth. In a simple barter economy profit may be expressed only in the form of an additional product. This product must be additionally produced by the economy. Therefore the sum of all profits and losses will be equal to the amount of the additionally produced product or, in other 
words, economic growth. Transaction costs are costs of each of us; they reduce our profit and cause economic growth to decline. A reduction in transaction costs will undoubtedly have a positive effect on growth. In a democracy, transaction costs are usually lower than in a dictatorship. An inverse relationship between the level of economic freedom and the amount of transaction costs does not cause any doubts, but the role of political rights is not so obvious. Political rights enable each one of us to participate in making important and not so important decisions. Laws may increase the profit of one group of the population and bring losses to another. Voting enables you to compare the amounts of profits and losses. If profits are greater than losses, then the receivers of the profit will be able to compensate the losses of the other group and still leave themselves some profit. Consequently, democracy enables you to achieve maximum profit and the maximum level of well-being.

One may doubt the sufficiency of the theoretical and empirical arguments in defence of the idea of the positive link between democratic changes and economic growth. Today, however, I do not see are serious grounds to criticise it. I believe that an important argument in its defence is the optimism of the idea. Of course, not all optimistic theories are true, but I do not know of one true pessimistic theory. And to those who continue to believe in the effectiveness of dictatorships, I can only recommend that they find themselves a dictator and try and share some money with him.

\section{References}

Acemoglu D., Johnson J., \& Yared P. (2008). Income and Democracy. American Economic Review. 98, 808-842. http://dx.doi.org/10.1257/aer.98.3.808

Alesina A., Ozler S., Roubini N., \& Swagel P. (1996). Political Instability and Economic Growth. Journal of Economic Growth. 1(2), 189-211. http://dx.doi.org/10.1007/BF00138862

Barro R.J., \& Sala-i-Martin X. (2004). Economic Growth. Second Edition. The MIT Press. P. 10- 14.

Barro R. J. (1996). Democracy and Growth. Journal of Economic Growth. 1, 3-27. http://dx.doi.org/10.1007/BF00138862

Barro R. J. (2012).Convergence and Modernization Revisited. National Bureau of Economic Research Working Paper. No 18295. August. http://dx.doi.org/10.1596/1813-9450-6027

Baum M., \& Lake D. (2003). Political Economy of Growth: Democracy and Human Capital. $\begin{array}{lllll}\text { American Journal of Political } & \text { Science. } & 47(2), & 33-347 .\end{array}$ http://dx.doi.org/10.1111/1540-5907.00023

Bilych G. (2012). Profit and Economic Growth. Business and Economic Research. 2(2). http://dx.doi.org/10.5296/ber.v2i2.2285

Boix C., \& Stokes S. (2003). Endogenous Democratization. World Politics. 55. 517-549. http://dx.doi.org/10.1353/wp.2003.0019

Clark G. (2007). A Farewell to Alms: A Brief Economic History of the World. Princeton University Press. 


\section{Macrothink}

Business and Economic Research ISSN 2162-4860 2013, Vol. 3, No. 1

Coase R. H. (1960). Problem of social cost. The Journal of Law and Economics. 3(1), 1-44. http://dx.doi.org/10.1086/466560

Coffee J. C. (1999). Privatization and Corporate Governance: The Lessons from Securities Market Failure. Columbia University Law School. N.Y.

Drury A., Krieckhaus J., \& Lusztig M. (2006). Corruption, Democracy, and Economic Growth. International Political Science Review. 27(2), 121-136. http://dx.doi.org/10.1177/0192512106061423

Durand J. (1977). Historical Estimates of World Population: An Evaluation. Population and Development Review. 3(3), 253-296. http://dx.doi.org/10.2307/1971891

Epstein D., Bates R., Goldstone J., Kristensen I., \& O`Holloran S. (2006). Democratic Transitions. American Journal of Political Science. 50, 551-569. http://dx.doi.org/10.1111/j.1540-5907.2006.00201.x

Feng Y. (2003). Democracy, Governance, and Economic Performance. Cambridge, MA: MIT Press.

Gerring J., Bond Ph., Barndt W., 7 Moreno C. (2005). Democracy and Growth: A Historical Perspective. World Politics. 57, 323-364. http://dx.doi.org/10.1353/wp.2006.0002

Greif A. (2006). Institutions and Path to the Modern Economy: Lessons from Medieval Trade. Cambridge: Cambridge Press. http://dx.doi.org/10.1017/CBO9780511791307

Hall R., \& Jones C. (1996). The Productivity of Nations. NBER Working Paper. No 5812.

Hu Z., \& Khan M. (1997). Why Is China Growing So Fast? International Monetary Fund. Economic Issues. No. 8. http://www.imf.org/external/pubs/ft/issues8/

Johnson S. (2000). Coase and Corporate Governance in Development. Villa Workshop Series.

Lake D., \& Baum M. (2001). The Invisible Hand of Democracy: Political Control and the Provision of Public Service. Comparative Political Studies. 34(6), 587-621. http://dx.doi.org/10.1177/0010414001034006001

Levin R., \& Renelt D. (1992). A Sensitivity Analysis of Cross-Country Growth Regression. American Economic Review. 82(4), 942-963.

Liew L. (2001). Democracy and Economic Growth in China. In: Beyond the Asian Crisis: Pathways to Sustainable Growth. Ed. by A. Chowdhyry, I. Islam. Northampton. MA, Edward Elgar.

Lipset S. (1959). Some Social Requisites of Democracy: Economic Development and Political Legitimacy. American Political Science Review. 53(March). P. 69-105. http://dx.doi.org/10.1177/0010414001034006001

McGuire M., \& Olson M. (1996). The Economics of Autocracy and Majority Rule: The Invisible Hand and the Use of Force. Journal of Economic Literature. 34(1), 72-96. 


\section{Macrothink}

Business and Economic Research ISSN 2162-4860 2013, Vol. 3, No. 1

Mokyr J. (2002). The Gifts of Athena. Historical Origins of the Knowledge Economy. Princeton University Press.

North D. C. (2005). Understanding the Process of Economic Change. Princeton University Press.

North D. C., \& Thomas R. P. (1973). The Rise of Western World: A New Economic History. Cambridge. Cambridge University Press. http://dx.doi.org/10.1017/CBO9780511819438

Okui K. (2005). Causality Between Political Freedom and Economic Freedom. Papers New Orleans Public Choice Annual Meeting.

Papaioannou E., Siourouunis G. (2008). Democratization and Growth. Economic Journal. 118(10), 1520-1551. http://dx.doi.org/10.1111/j.1468-0297.2008.02189.x

Persson T., \& Tabellini G. (2006). Democracy and Development: The Devil in the Details. American Economic Review Paper and Proceedings. 99, 314-319. http://dx.doi.org/10.1257/000282806777212396

Przevorski A., Alvarez M., Cheibub J., \& Limongi F. (2000). Democracy and Development. Political Institutions and Well-Being in the World 1950-2000. Cambridge University Press. http://dx.doi.org/10.1017/CBO9780511804946.002

Rawls J. (1971). A Theory of Justice. Cambridge. Massachusetts: Belknap Press of Harvard University Press.

Rodrik D. (1997). Democracy and Economic Performance. A Paper for a Conference in South Africa. http://www.ksg.harvard.edu/rodrik/.

Rueschemeyer D., Stephens E., \& Stephens J. (1992). Capitalist Development and Democracy. Chicago: University of Chicago Press.

Sala-i-Martin X. (1997). I Just Ran Two Million Regressions. AEA Papers and Proceeding. 87, 178-183.

Schneider L., (1963). Preface to: K. Menger. Problems of Economics and Sociology. Urbana: University of Illinois Press. P.16.

Sen A. (1997). Human Rights and Asian Values: What Lee Kuan Yew and Lee Peng Don`t Understand About Asia. The New Republic. July 14. Vol. 217. No 2-3.

Siegle J., Wenstein M., \& Halperin M. (2004). Why Democracies Excel. Foreign Affairs. 83, 57-71. http://dx.doi.org/10.2307/20034067

Vlfelder J., \& Lustik M., Modeling Transition to Democracy. Democratization. 14, 357-387.

Welzel Ch., Inglehart R. (2005). Liberalism, Postmaterialism, and the Growth of Freedom: The Human Development Perspective. International Review of Sociology. 15(1). http://dx.doi.org/10.1080/03906700500038579 


\section{Macrothink}

Business and Economic Research ISSN 2162-4860 2013, Vol. 3, No. 1

Welzel Ch., \& Inglehart R. (2008). The Role of Ordinary People in Democratization. Journal of Democracy. 19(1), 126-140. http://dx.doi.org/10.1353/jod.2008.0009

Wilke T. (2002). The Investment Theory of Wars: Beligerent Dictators in the McGuire/North-Model of Autocracy. Public Choice. 112(3-4), 319-333. http://dx.doi.org/10.1023/A:1019960228661

Wo W., \& Otto A. (2005). Freedom and Growth: A Dynamic Panel Data Model. Papers New Orleans Public Choice Annual Meeting.

Yao Y., \& Yueh L. (2009). Law, Finance, and Economic Growth in China: An Introduction. World Development. 37(4), 753-762. http://dx.doi.org/10.1016/j.worlddev.2008.07.009

Zakaria F. (2003). The Future of Freedom: Illiberal Democracy at Home and Abroad. NY: W.W. Norton and Co.

\section{Copyright Disclaimer}

Copyright reserved by the author(s).

This article is an open-access article distributed under the terms and conditions of the Creative Commons Attribution license (http://creativecommons.org/licenses/by/3.0/). 